\title{
Effect of Vanadium Addition at a Rate of $0.1 \%$ on the Mechanical Characteristics, Microstructure, and Microhardness of Al-Cu Casted Alloys
}

\author{
A. A. Mahasneh \\ Department of Applied Physics, Faculty of Science, Tafila Technical University \\ P. O. Box: 179, Tafila 66110 (Jordan) \\ Tel: 96-27-9626-2750 E-mail: d_aamahasneh@yahoo.com
}

\author{
S. M. A. Al-Qawabah \\ Department of Mechanical Engineering, Faculty of Engineering, Tafila Technical University \\ P. O. Box: 179, Tafila 66110 (Jordan) \\ Tel: 96-27-7749-9418Ｅ-mail: safwan_q@yahoo.com
}

Received: December 25, 2010

Accepted: January 19, 2011

doi:10.5539/mas.v5n2p92

\begin{abstract}
Due to essential need of Al-Cu alloys in different applications such as aerospace and automotive industries, and the mechanical characteristics of Al-Cu alloys being weak; the effect of vanadium addition at a rate of $0.1 \%$ on the mechanical behavior, microhardness, and microstructure have been investigated. The effect of upsetting process -cold work- on the microstructure, microhardness has been also investigated. Three set of alloys namely; $\mathrm{Al}, \mathrm{Al}-9 \% \mathrm{Cu}$, and $\mathrm{Al}-9 \% \mathrm{Cu}-0.1 \% \mathrm{~V}$ were prepared. The specimens for microstructure, microhardness and compression tests were machined. The mechanical tests were performed to investigate the effect of vanadium addition and the effect of upsetting process. It was found that the $0.1 \%$ vanadium addition resulted in grain refinement of $\mathrm{Al}-9 \% \mathrm{Cu}$ alloys of about $32.3 \%$, furthermore, and extra refining resulted after upsetting process by $44.2 \%$. On the other hand, the microhardness of Al-9\% Cu enhanced by $54.1 \%$, and the valuable result was a $422.8 \%$ enhancement in the microhardness of $\mathrm{Al}-9 \% \mathrm{Cu}-0.1 \% \mathrm{~V}$ alloy after upsetting process compared to pure Al.
\end{abstract}

Keywords: Copper, Vanadium, Grain refinement, Microhardness, Microstructure, Upsetting process

\section{Introduction}

Owing to their low weight, high strength, good corrosion resistance and easy casting the $\mathrm{Al}-\mathrm{Cu}-\mathrm{Si}-\mathrm{Mg}$ alloys have a wide range of usage in automotive and aerospace industries (Kilass and Radimilovic, 2001; Reif et al., 1997). Aluminum alloys with transition metals are a promising base for fabricating super high-temperature and light alloys that can be used as matrices for composite materials (Drits, 1985). Transition metals are characterized by strong interatomic bonding and low diffusivity in solid aluminum, and the limiting solubility of these metals in the solid solution is very low. The use of such treatment methods as laser heating and spinning, which ensure a cooling rate of the metal on the order of $106 \mathrm{~K} / \mathrm{s}$, promotes the appearance of metastable phases (Bainbridge and Adam, 1975), including aluminum-base supersaturated solid solutions (SSS) and the content of alloying elements in which exceeds their limiting solubility in equilibrium state (Dobatkin, 1975).

Addition of copper to $\mathrm{Al}-\mathrm{Si}$ alloys can form $\mathrm{CuAl}_{2}$ phases and other intermetallic compounds, which increase strength of casting parts (Gautheir et al., 1994; Mulazimoglu et al., 1995; and Samuel et al., 1996). Copper also increases heat treatability of the alloy. Addition of copper decreases significantly the melting point and eutectic temperature of the alloy. Therefore, the copper increases the solidification range of the alloy (Anylalebechi, 1995; and Cacers et al., 1999).

The effect of microalloying aluminum and its alloys by different refractory metals and the effect of addition of some transition materials namely $\mathrm{V}$ and $\mathrm{Zr}$ on the mechanical behavior and machinability of commercially pure aluminum have been also investigated (Zaid and Abdl-Hamid, 2000; Zaid and Abdl-Hamid, 2001). The grain efficiency is affected by many factors under three headings namely; parameters related to Al or Al alloy melt, parameters related to the grain refiner itself, and parameters related to the procedure followed in carrying out the grain refinement process. It has been also reported that the effectiveness of the grain refinement depends on the purity of the Al melt (Jones and Pearson, 1976).

This study has been motivated to investigate the prominent effects of $0.1 \%$ vanadium addition on the microstructure, microhardness, and mechanical properties of $\mathrm{Al}-9 \% \mathrm{Cu}$ casted alloy. Furthermore, the effect of the upsetting process on the produced alloys namely $\mathrm{Al}, \mathrm{Al}-9 \% \mathrm{Cu}$, and $\mathrm{Al}-9 \% \mathrm{Cu}-0.1 \% \mathrm{~V}$ are presented and studied. 


\section{Materials, Equipment, and Experimental Procedures}

\subsection{Materials}

In this study, pure aluminum rod was used. Copper and vanadium powder were used to prepare the required alloys.

\subsubsection{Aluminum}

Commercially pure aluminum of $98.85 \%$ purity was used as rods, and its chemical composition shown in Table.1, is analyzed by X-ray fluorescence technique (XRF model 1800- shemadzu, Japan).

\subsubsection{Copper}

Pure copper is used extensively as cable, wire, and pure powder. The density of copper is $9.95 \mathrm{gm} . \mathrm{cm}^{-3}$ and the melting point is $1080^{\circ} \mathrm{C}$. Copper has many important advantages; its corrosion resistance, easily fabricated, high electrical and thermal conductivity. Copper of $99.99 \%$ purity was used.

\subsubsection{Vanadium}

Vanadium was used as a powder of $99.99 \%$ purity, where its melting point is $1910^{\circ} \mathrm{C}$ and its density is 6 $\mathrm{gm} . \mathrm{cm}^{-3}$.

\subsection{Equipment}

A set of machines and equipment were used through out the experimental work:

An electric resistance furnace (Carbolite) with $0-1100^{\circ} \mathrm{C}$ has been used for melting the base materials. Casting mould has been used to cast the molten metals. the elemental contents of the casted alloys have been analyzed using XRF (Model 1800- shemadzu, Japan) technique. Digital microhardness tester (model HWDM-3) was used to determine the hardness of the casted alloys (in Hv).

Universal Testing Machine with 100KN capacity (Quasar 100) was used to perform the upsetting test.. the microstructure phtomicroscan for the cated alloys has been carried out using a Microscope type (NIKON 108). $\mathrm{CNC}$ lathe machine (Boxford) was used to prepre the required dimensions of the specimens.

\subsection{Experimental Procedures}

\subsubsection{Master alloy preparation}

Binary $\mathrm{Al}-5 \% \mathrm{~V}$ was prepared by melting $95 \mathrm{gm}$ of pure aluminum, and then $5 \mathrm{gm}$ of vanadium powder was added to the $\mathrm{Al}$ molten metal. After that, the mixture is steered for two minutes, the mixture return back to furnace for $30 \mathrm{~min}$, and then it poured on cast iron plate. The XRF analysis was used to insure the vanadium percentage.

\subsubsection{Microalloy preparation}

$\mathrm{Al}-9 \% \mathrm{Cu}$ alloy was prepared by adding $18 \mathrm{gm}$ copper to $182 \mathrm{gm}$ of pure aluminum, and $\mathrm{Al}-9 \% \mathrm{Cu}-0.1 \% \mathrm{~V}$ alloy was prepared by adding the precalculated mass from $\mathrm{Al}-5 \% \mathrm{~V}$ master alloy. The molten mixture of each alloy was poured in special brass mold shown in Fig. 1. The brass mold is prepared by CNC lathe machine. The Al alloys in the as cast condition are shown in Table.2.

\subsubsection{Microstructure test}

A specimen from each of $\mathrm{Al}, \mathrm{Al}-9 \% \mathrm{Cu}$, and $\mathrm{Al}-9 \% \mathrm{Cu}-0.1 \% \mathrm{~V}$ alloys was mounted then grinded using emery paper of 200,400,600,800, 1000, and 1200 grades, followed by diamond baste, and then etched using (5\% $\mathrm{HNO}_{3}, 3 \% \mathrm{HCL}, 4 \% \mathrm{HF}$, and $88 \% \mathrm{H}_{2} \mathrm{O}$ ) solution in order to get a clear microstructure for each casted alloy.

2.3.4 Microhardness test

Microhardness test was carried out using HWDM-3 microhardness tester at $200 \mathrm{gm}$ force on $\mathrm{Al}, \mathrm{Al}-9 \% \mathrm{Cu}$, and $\mathrm{Al}-9 \% \mathrm{Cu}-0.1 \% \mathrm{~V}$ casted alloys. Five microhardness readings were taken for each alloy from which the average microhardness was calculated.

\subsubsection{Compression test}

Cylindrical specimens of $15 \mathrm{~mm}$ diameter and $15 \mathrm{~mm}$ length were machined using Boxford CNC lathe machine. The prepared cylindrical specimens were subjected to compression test at room temperature using (Quasar 100 Universal Testing Machine with $100 \mathrm{KN}$ capacity) at $1 * 10^{-3} / \mathrm{s}$ strain rate. The load-deflection curve (see appendix-A, Fig.A-1) was obtained for each type of the prepared alloys from which the true stress-true strain curve was determined. The compression test was repeated three times for each alloy, and then the average of load-deflection has been calculated. Fig.2 illustrates the specimen before and after upsetting process.

\subsubsection{Average grain size measurement}

Line intercept method was used to determine the average grain size using Digital microhardness tester (model HWDM-3) at 400x magnification.

\section{Results and Discussion}

\subsection{Effect of vanadium addition at a rate of $0.1 \%$ on the microstructure of $\mathrm{Al}-9 \% \mathrm{Cu}$ casted alloys}

It can be shown from Fig.3 (a) that aluminum has a course columnar structure which indicates that the mechanical properties are weak. Based on the Al-Cu binary phase diagram (see appendix-A, Fig. A-2), 9\% of 
copper has been added to the Al. This addition reduced the average grain size, where $\mathrm{Cu}$ was precipitated on the grain boundary and distributed throughout the grains as shown Fig.3 (b). This can be attributed to the formation of intermetallic compound $\mathrm{CuAl}_{2}$ (Gautheir et al., 1994; Mulazimolgu et al., 1995; and Samuel et al., 1996). A new addition of $0.1 \%$ vanadium to $\mathrm{Al}-9 \% \mathrm{Cu}$ alloy showed a prominent reduction in the average grain size, and this reduction is accounted to the formulation of $\mathrm{Al}_{21} \mathrm{~V}_{2}$ intermetallic compound as shown in Fig. 3 (c). In the following sections, the microhardness and mechanical tests clarify how the reduction in grain size affects the mechanical properties of Al-Cu alloy.

\subsection{Effect of upsetting process on the average grain size of Al-9\%Cu grain refined by $0.1 \%$ vanadium}

It can be seen from Fig.4 that after the upsetting process (cold work), further reduction in the average grain size was attained, and this reduction is expected to show a prominent enhancement in the mechanical properties of $\mathrm{Al}-9 \% \mathrm{Cu}-0.1 \% \mathrm{~V}$.

\subsection{Effect of vanadium addition at a rate of $0.1 \%$ on the average grain size of Al-9\%Cu casted alloys}

It is obviously illustrated by Fig. 5 that the grain size of Al was reduced by 3.65 times (124-34 $\mu \mathrm{m})$ after adding $9 \%$ $\mathrm{Cu}$ to $\mathrm{Al}$, and the addition of $0.1 \% \mathrm{~V}$ to $\mathrm{Al}-9 \% \mathrm{Cu}$ increases the average grain size by $32.3 \%(34-45 \mu \mathrm{m})$. According to hall pitch equation, the inverse relation between the mechanical properties and the grain diameter is given by:

$$
\sigma_{\mathrm{y}}=\sigma_{\mathrm{o}}+\left(\frac{\mathrm{k}_{\mathrm{y}}}{\sqrt{\mathrm{d}}}\right)
$$

where $\sigma_{\mathrm{y}}$ is the yield stress, $\sigma_{\mathrm{o}}$ and $\mathrm{k}_{\mathrm{y}}$ are constants for a particular material. $\mathrm{d}$ is the average grain diameter. 3.4 Effect of upsetting process on the average grain size of Al-9\%Cu alloy grain refined by vanadium It is obviously shown in Fig.6 that the average grain size of upsetted pure Al was refined by $42.9 \%(38.5-22 \mu \mathrm{m})$ and $44.2 \%(38.5-21.5 \mu \mathrm{m})$ for upsetted $\mathrm{Al}-9 \% \mathrm{Cu}$ alloy and upsetted $\mathrm{Al}-9 \% \mathrm{Cu}-0.1 \% \mathrm{~V}$ alloy respectively. This enhancement is attributed to the cold work process; the strain hardening process, in which the original grain boundaries destroyed followed by re-crystallization and grain growth.

The direct comparison between the grain refinement of $\mathrm{Al}, \mathrm{Al}-9 \% \mathrm{Cu}$ and $\mathrm{Al}-9 \% \mathrm{Cu}$ before and after the upsetting process is illustrated by Fig. 7. It is worth to mention that, before the upsetting process, the average grain size after adding $9 \% \mathrm{Cu}$ is larger than that of $0.1 \% \mathrm{~V}$ addition, whereas the average grain size, after the upsetting process, for $0.1 \% \mathrm{~V}$ addition is larger than that of $9 \% \mathrm{Cu}$ addition. This finding throws a significant remark for further alloys fabrication. By other words, a micro-level addition of a transition element like vanadium followed by upsetting process is highly recommend for Al industry .

\subsection{Effect of $9 \% \mathrm{Cu}$ and $0.1 \% \mathrm{~V}$ addition on the maximum density of pure $\mathrm{Al}$}

As indicated by Fig. 8 , the maximum density of Al is increased by $20.8 \%$ (from $2.7-3.2616$ gm $/ \mathrm{cm}^{3}$ ) after $0.9 \%$ $\mathrm{Cu}$ addition. On the other hand, it is slightly changed after $0.1 \% \mathrm{~V}$ addition, and this slight change is accounted to micro level addition of vanadium. Although the change in maximum density after vanadium addition is small, the structure is completely refined.

\subsection{Effect of vanadium addition at a rate of $0.1 \%$ on the microhardness of Al-9\%Cu casted alloys}

Fig. 9 shows a $108.1 \%(28.5-59.3 \mathrm{Hv})$ enhancement in the hardness of pure $\mathrm{Al}$ after adding $9 \% \mathrm{Cu}$, and this enhancement is accounted to $\mathrm{CuAl}_{2}$ intermetallic compound formulation that hindering the grain growth. Further enhancement of 53.4\% (59.3-91.4 Hv) was achieved after adding $0.1 \% \mathrm{~V}$, which formulates the $\mathrm{Al}_{21} \mathrm{~V}_{2}$ intermetallic compound.

\subsection{Effect of upsetting process on the microhardness of Al-9\%Cu grain refined by vanadium}

Fig. 10 shows that the microhardness of $\mathrm{Al}-9 \% \mathrm{Cu}$ alloy was slightly decreased after upsetting process despite that the average grain size was decreased. After the upsetting process, the microhardness is increased by $157.8 \%$ (57.8-149 Hv) after adding $0.1 \% \mathrm{~V}$, and this increase can be clarified by grain refinement and internally existence of $\mathrm{Al}_{21} \mathrm{~V}_{2}$ intermetallic compound inside the grain. It is valuable to now that there is a $422.8 \%$ (28.5-149 $\mathrm{Hv}$ ) enhancement in the microhardness of $\mathrm{Al}-9 \% \mathrm{Cu}-0.1 \% \mathrm{~V}$ after upsetting process compared to pure Al. Consequently, it is not recommended to conduct upsetting process after $9 \% \mathrm{Cu}$ addition before adding a micro level of vanadium, but a significant refinement can be attained by performing the upsetting process to Al- $9 \% \mathrm{Cu}$ after adding vanadium. As an interesting result, it is clearly noticed that the addition of a transition element such as vanadium followed by upsetting process reduce the average grain size, and this reduction is accompanied with a reasonable microhardness enhancement. These distinguished results should be implemented in $\mathrm{Al}$ industry.

\subsection{Effect of vanadium addition on the mechanical characteristics of $\mathrm{Al}-9 \% \mathrm{Cu}$}

It can be seen from Fig. 11 that the mechanical behavior is enhanced by $66.7 \%$ at $9 \% \mathrm{Cu}$ addition, and a better enhancement of $200 \%$ is achieved after adding $0.1 \% \mathrm{~V}$, where this comparison was done at 0.2 strain. The addition of $0.1 \% \mathrm{~V}$ is based on the binary phase diagram of Al-V (see as appendix A, Fig. A-3). This highly 
detected enhancement is attributed to grain refinement and internally existence of $\mathrm{Al}_{21} \mathrm{~V}_{2}$ intermetallic compound inside the grain that resulted after vanadium addition.

\section{Conclusions}

Grain refinement, microhardness, and mechanical characteristics of pure $\mathrm{Al}, \mathrm{Al}-9 \% \mathrm{Cu}$ alloy, and $\mathrm{Al}-9 \% \mathrm{Cu}-$ $0.1 \% \mathrm{~V}$ alloy have been studied. The effect of conducting upsetting process on the grain refinement and microhardness of the casted alloys has also been investigated. Many significant conclusions can be drawn from the findings of this comprehensive experimental study:

- The average grain size of pure $\mathrm{Al}$ was refined by 3.65 times after adding $9 \% \mathrm{Cu}$.

- The average grain size was refined by $32.3 \%$ after adding $0.1 \% \mathrm{~V}$ to $\mathrm{Al}-9 \% \mathrm{Cu}$ alloy.

- The average grain size of the upsetted $\mathrm{Al}-9 \% \mathrm{Cu}$ alloy was refined by $42.9 \%$ compared to upsetted pure Al.

- The average grain size of upsetted $\mathrm{Al}-9 \% \mathrm{Cu}-0.1 \% \mathrm{~V}$ was refined by $44.2 \%$ compared to upsetted pure Al.

- The change in maximum density of $\mathrm{Al}-9 \% \mathrm{Cu}$ is slightly small after adding $0.1 \% \mathrm{~V}$, however, the structure is completely grain refined.

- a $108.1 \%$ enhancement in the hardness of pure $\mathrm{Al}$ after adding $9 \% \mathrm{Cu}$ was attained, and a further enhancement of $54.1 \%$ is also attained by adding $0.1 \% \mathrm{~V}$.

- It is worth to mention that there is a $422.8 \%$ enhancement in the microhardness of $\mathrm{Al}-9 \% \mathrm{Cu}-0.1 \%$ $\mathrm{V}$ after upsetting process compared to pure $\mathrm{Al}$.

- The mechanical behavior was enhanced by $66.7 \%$ at $9 \% \mathrm{Cu}$ addition, where the enhancement is $200 \%$ that achieved after $0.1 \%$ vanadium addition.

- As an interesting result, it is clearly noticed that the addition of a transition element such as vanadium followed by upsetting process reduce the average grain size, and this reduction is accompanied with a reasonable microhardness enhancement. These distinguished results should be implemented in Al industry.

\section{Acknowledgement}

This study has been supported by Tafila Technical University under grant No. (82/2010). The efforts of the technical staff at mechanical engineering department are highly appreciated. The authors would like to thank students: Ibtehal Bdoor, Tareq Sameer, and Mohannad Jaber for their distinguished performance during the course of this study.

\section{References}

A.I.O. Zaid, A.A. Abdel-Hamid.(2000). Effect of zirconium addition on Mechanical behavior and machinability of aluminum, $15^{\text {th }}$ international conference on production research ICRP-15, Bangkok, Thailand.

A.I.O. Zaid, A.A. Al-Alami. (2001). Effect of vanadium on the fatigue life of aluminum, ICPR-16, Proc. Int. Conf. on Production Research, Prague, Chzech.

C.H. Cacers, M.B. Djurdjevic, T.J. Stockwell, J.H. Sokolowski. (1999). The effect of Cu content on the level of microporosity in Al-Si-Cu-Mg casting alloys, Scripta Mater. 40 (5): 631-637.

F.H. Samuel, A.M. Samuel, H.W. Doty.(1996). Factors controlling the type and morphology of Cu-containing phases in $319 \mathrm{Al}$ alloy, AFS Trans. 104: 893-901.

G.P. Jones, J.Pearson. (1976). Factors affecting the grain refinement of aluminum using titanium and boron additives, met. Trans. $B$, pp. 223-234

J. Gautheir, P.R. Louchez, F.H. Samuel.(1994). Heat treatment of 319.2 aluminum automotive: part 1: Solution heat treatment, Cast Met. 8 (2): 91-106.

L. F. Bainbridge and C. M. Adam.(1975).Aluminum Alloys, Australian Patent No. 468234.

M. E. Drits.(1985). Stable and Metastable Phase Equilibria in Metallic Systems [in Russian], Nauka, Moscow (1985).

M.H. Mulazimoglu, N. Tenekedjiev, B.M. Closset, J.E. Gruzleski.(1995, 1991). The minor reactions and phases in Sr treated aluminum-silicon casting alloys, American Foundrymen's Society.

P.N. Anyalebechi. (1995). Analysis of the effects of alloying elements on hydrogen solubility in liquid aluminum alloys, Scripta. Mater. 33 (8): 1209-1216.

R. Kilaas, V. Radmilovic, Structure determination and structure refinement of A12CuMg precipitates by quantitative high-resolution electron microscopy, Ultramicroscopy 88 (2001) 63-72.

V. I. Dobatkin and V. I. Elagin.(1975). Granulated Aluminum Alloys [inRussian], Metallurgiya, Moscow.

W. Reif, J. Dutkiewicz, R. Ciach, S. Yu, J. Krol. (1997). Effect of ageing on the evolution of precipitates in AlSiCuMg alloys, Mater. Sci. Eng. A 234-236:165-168. 
Table 1. Chemical composition of commercially pure aluminum

Table 2. The Al alloys and microalloys in the as cast condition

\begin{tabular}{|c|c|c|c|c|c|}
\hline Elements & $\mathrm{Al}$ & $\mathrm{Cu}$ & $\mathrm{Si}+\mathrm{Fe}$ & $\mathrm{Mn}$ & $\mathrm{Zn}$ \\
\hline$\% \mathrm{wt}$ & 98.85 & $0.05-0.2$ & 0.95 & 0.05 & 0.1 \\
\hline
\end{tabular}

\begin{tabular}{|c|c|c|c|}
\hline $\mathrm{Al}-\mathrm{Alloy}$ & $\mathrm{Al}(\mathrm{wt} \%)$ & $\mathrm{Cu}(\mathrm{wt} \%)$ & $\mathrm{V}(\mathrm{wt} \%)$ \\
\hline $\mathrm{Al}$ & 100 & 0.0 & 0.0 \\
\hline $\mathrm{Al}-9 \% \mathrm{Cu}$ & 91 & 9.0 & 0.0 \\
\hline $\mathrm{Al}-9 \% \mathrm{Cu}-0.1 \% \mathrm{~V}$ & 90.9 & 9.0 & 0.1 \\
\hline
\end{tabular}

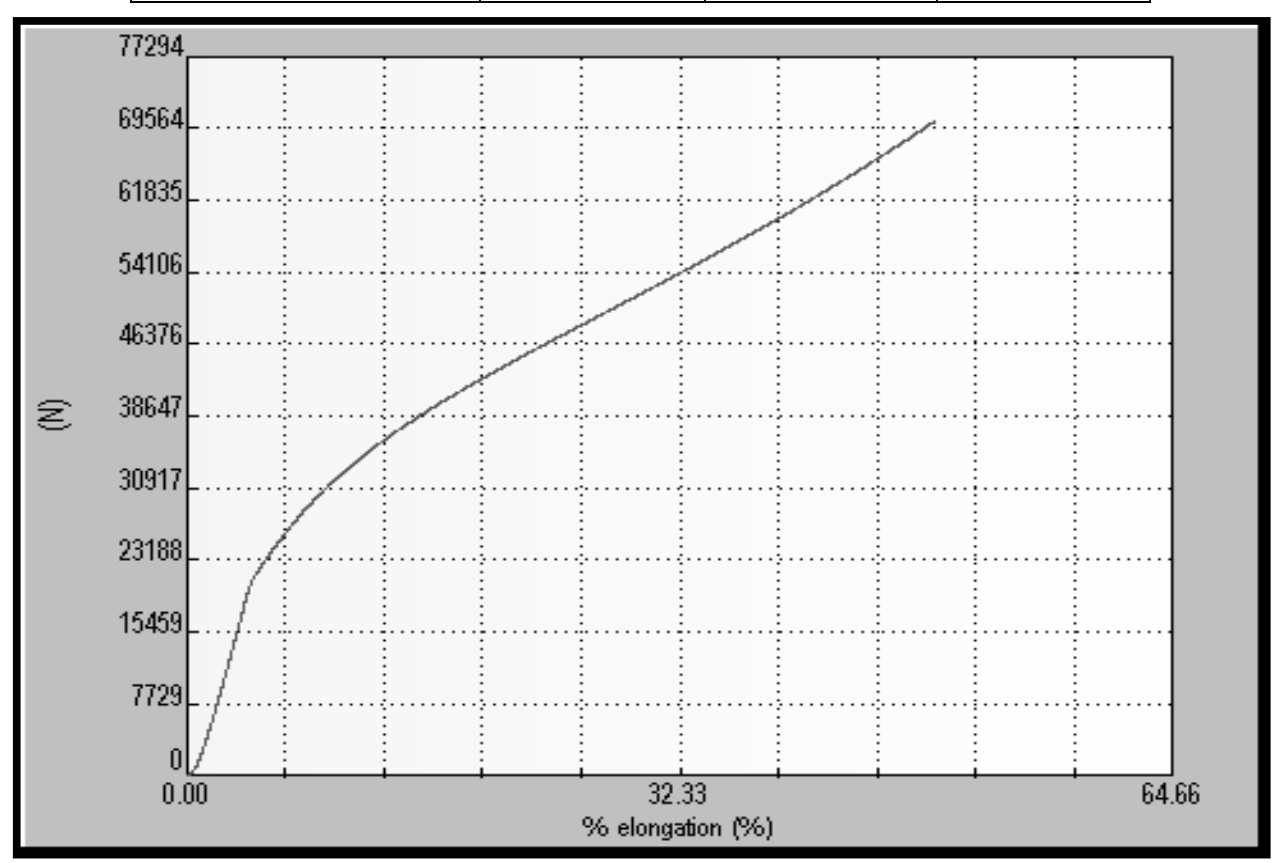

Figure A-1. Autographic record (load-elongation) based on compression test for $\mathrm{Al}-9 \% \mathrm{Cu}-0.1 \% \mathrm{~V}$ casted alloys

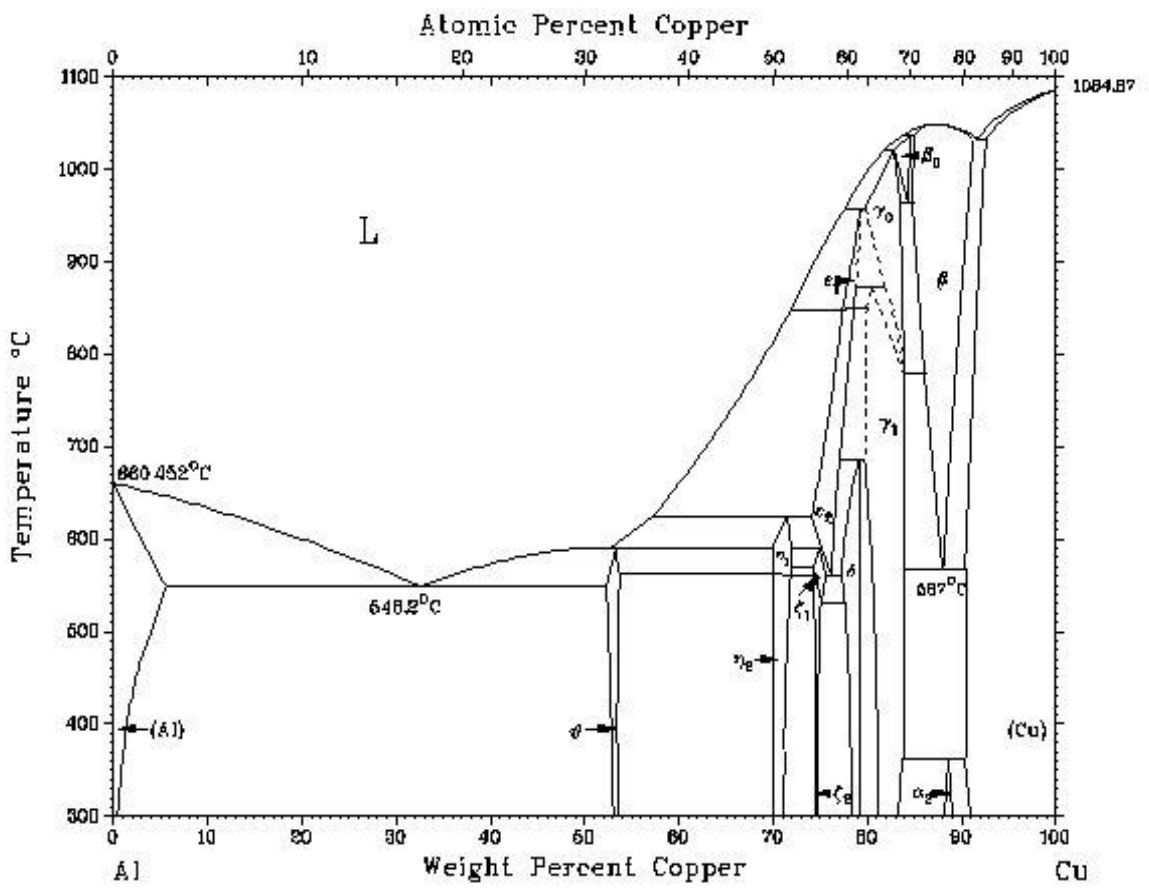

Figure A-2. Binary phase diagram of Al-Cu alloy 


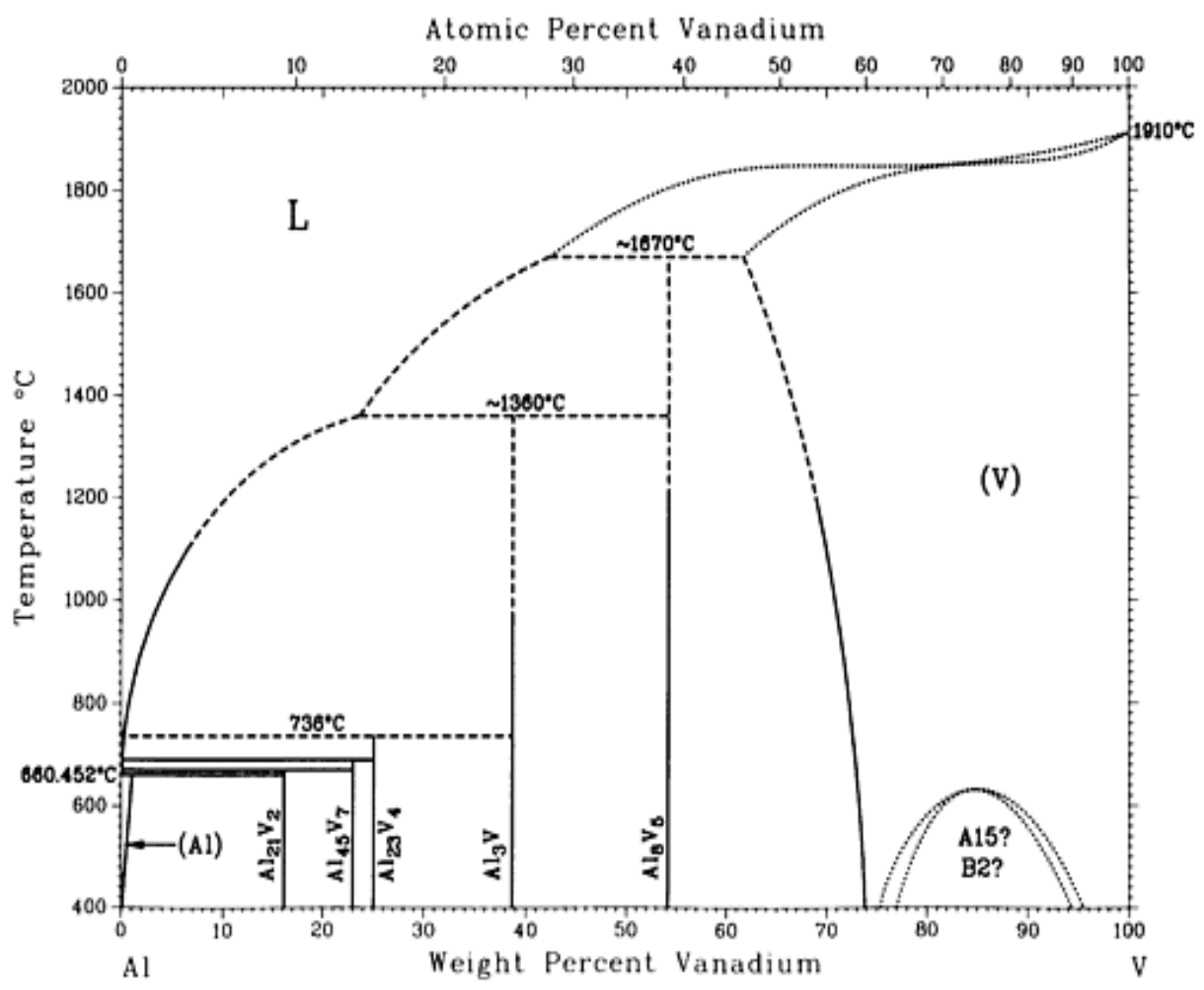

Figure A-3. Binary phase diagram of Al-V alloy

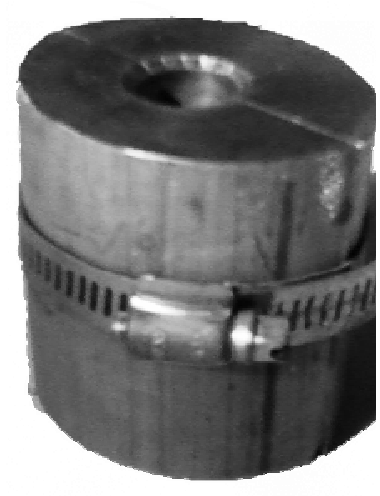

Figure 1. Brass mold

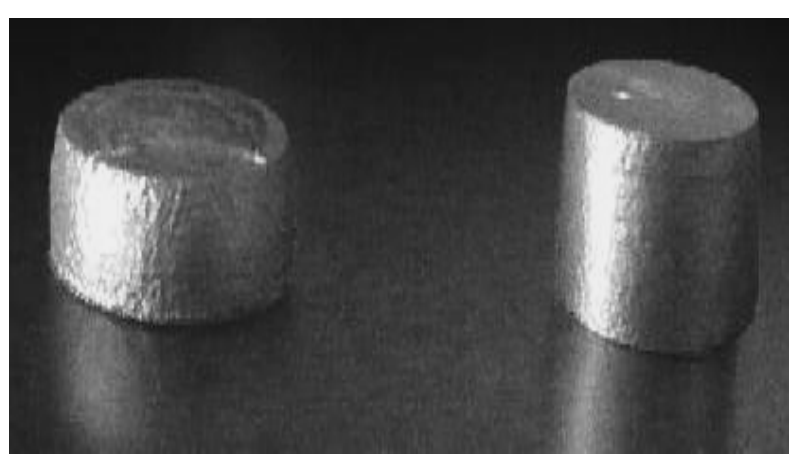

Figure 2. Compression test specimen 

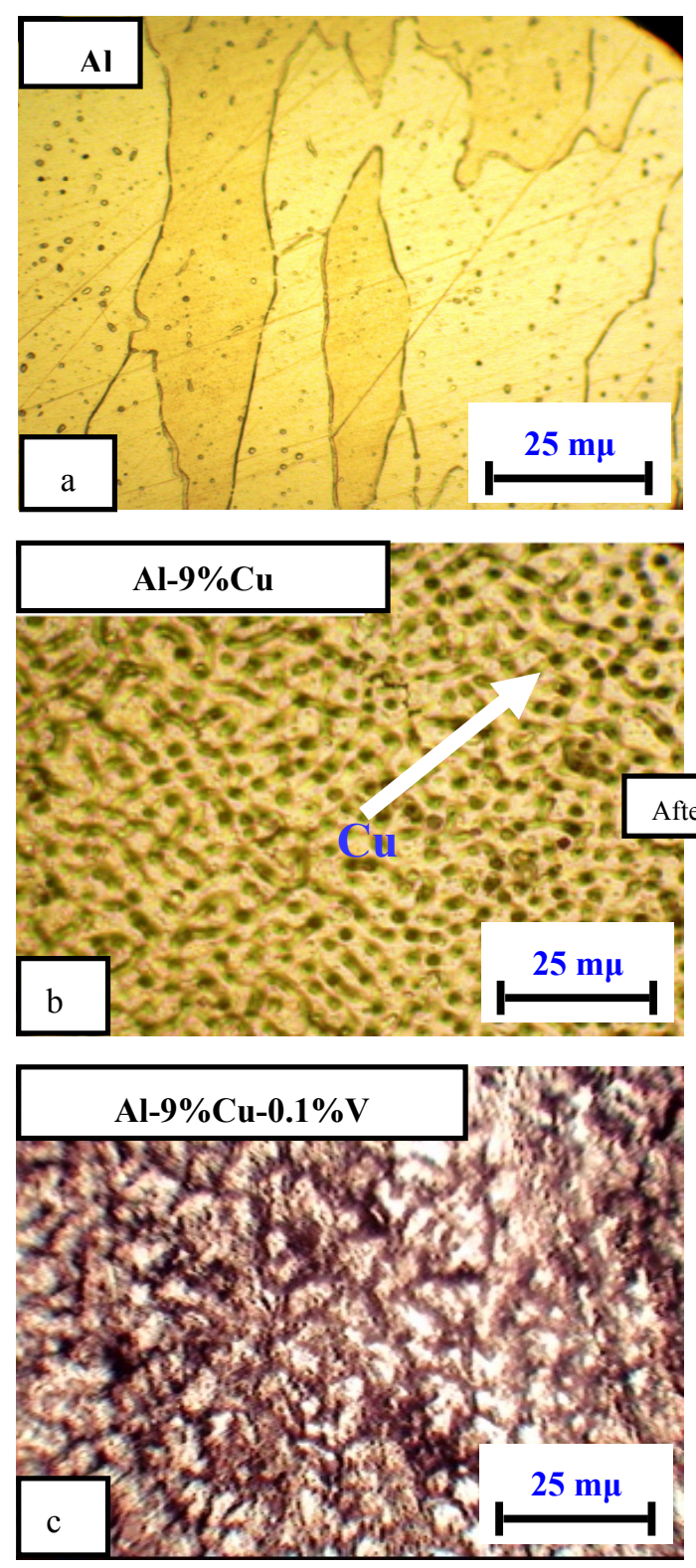

Figure 3. Photomicroscan of a) pure $\mathrm{Al}, \mathrm{b}$ ) Al-9 \% Cu alloy, and c) Al-9 \% Cu- $0.1 \% \mathrm{~V}$ alloy at $400 x$. The dark regions in photo-b represent $\mathrm{Cu}$ precipitate.
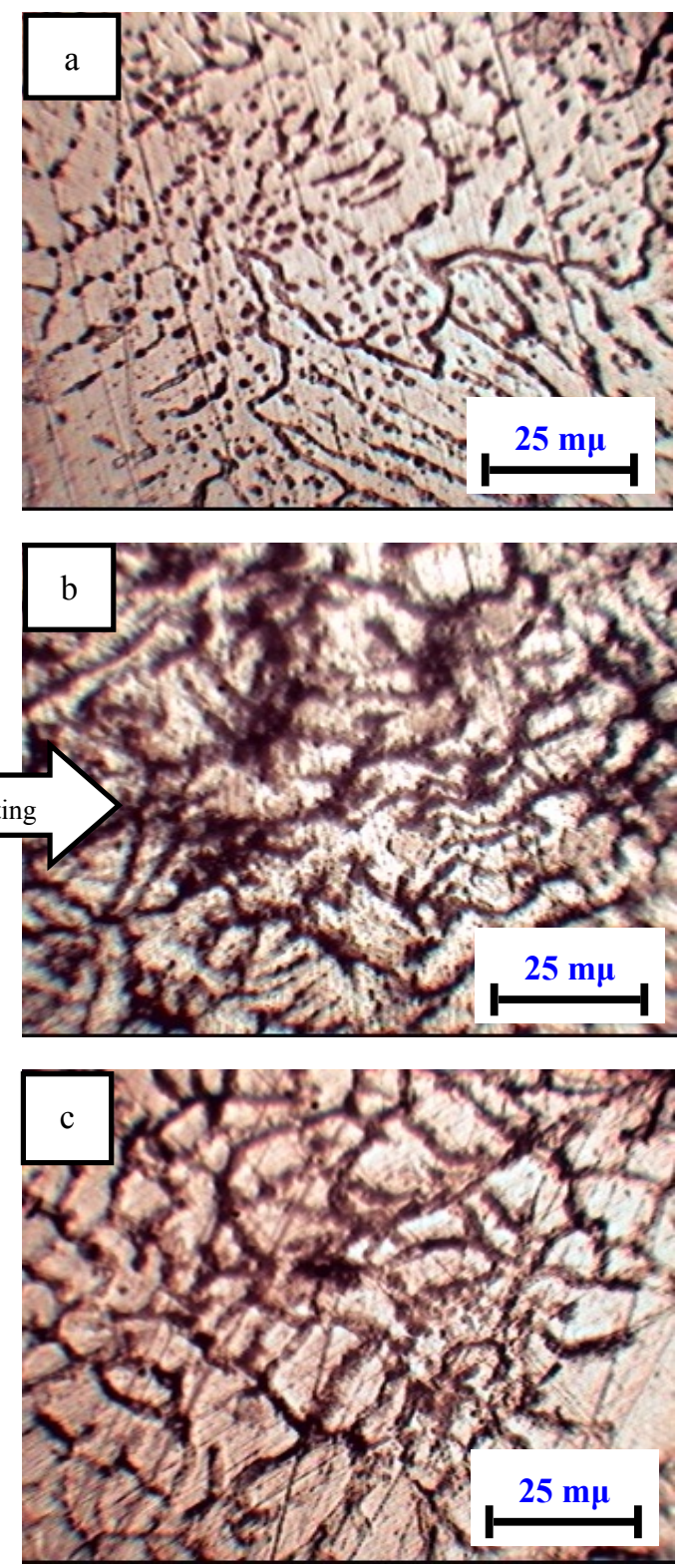

Figure 4. Photomicroscan of a) pure $\mathrm{Al}, \mathrm{b}$ ) $\mathrm{Al}$ $9 \% \mathrm{Cu}$ alloy, and c) $\mathrm{Al}-9 \% \mathrm{Cu}-0.1 \% \mathrm{~V}$ alloy after upsetting process at 400x.crystallization and grain growth. 


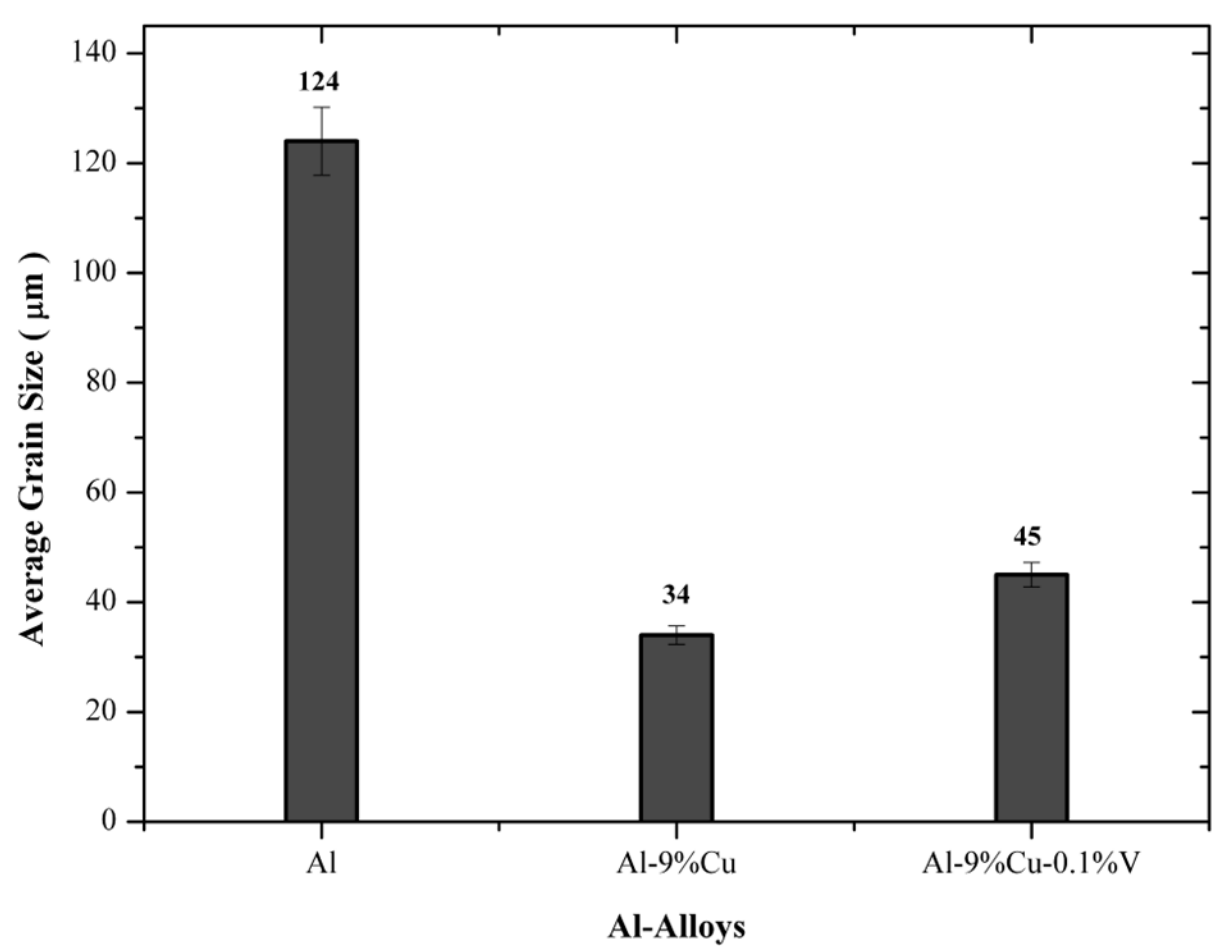

Figure 5. Average grain size of pure $\mathrm{Al}, \mathrm{Al}-9 \% \mathrm{Cu}$ alloy, and $\mathrm{Al}-9 \% \mathrm{Cu}-0.1 \% \mathrm{~V}$ alloy before upsetting process

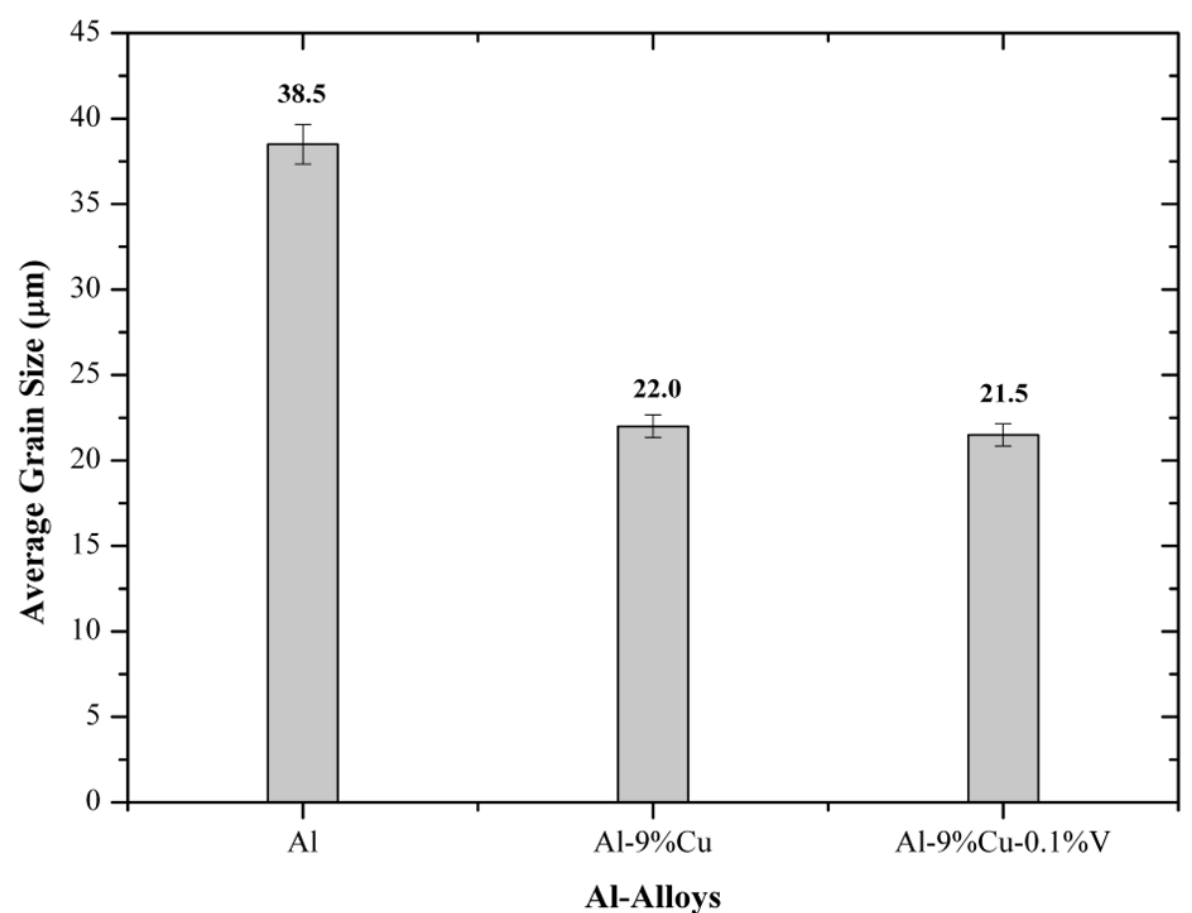

Figure 6. Average grain size of pure $\mathrm{Al}, \mathrm{Al}-9 \% \mathrm{Cu}$ alloy, and $\mathrm{Al}-9 \% \mathrm{Cu}-0.1 \% \mathrm{~V}$ alloy after upsetting process 


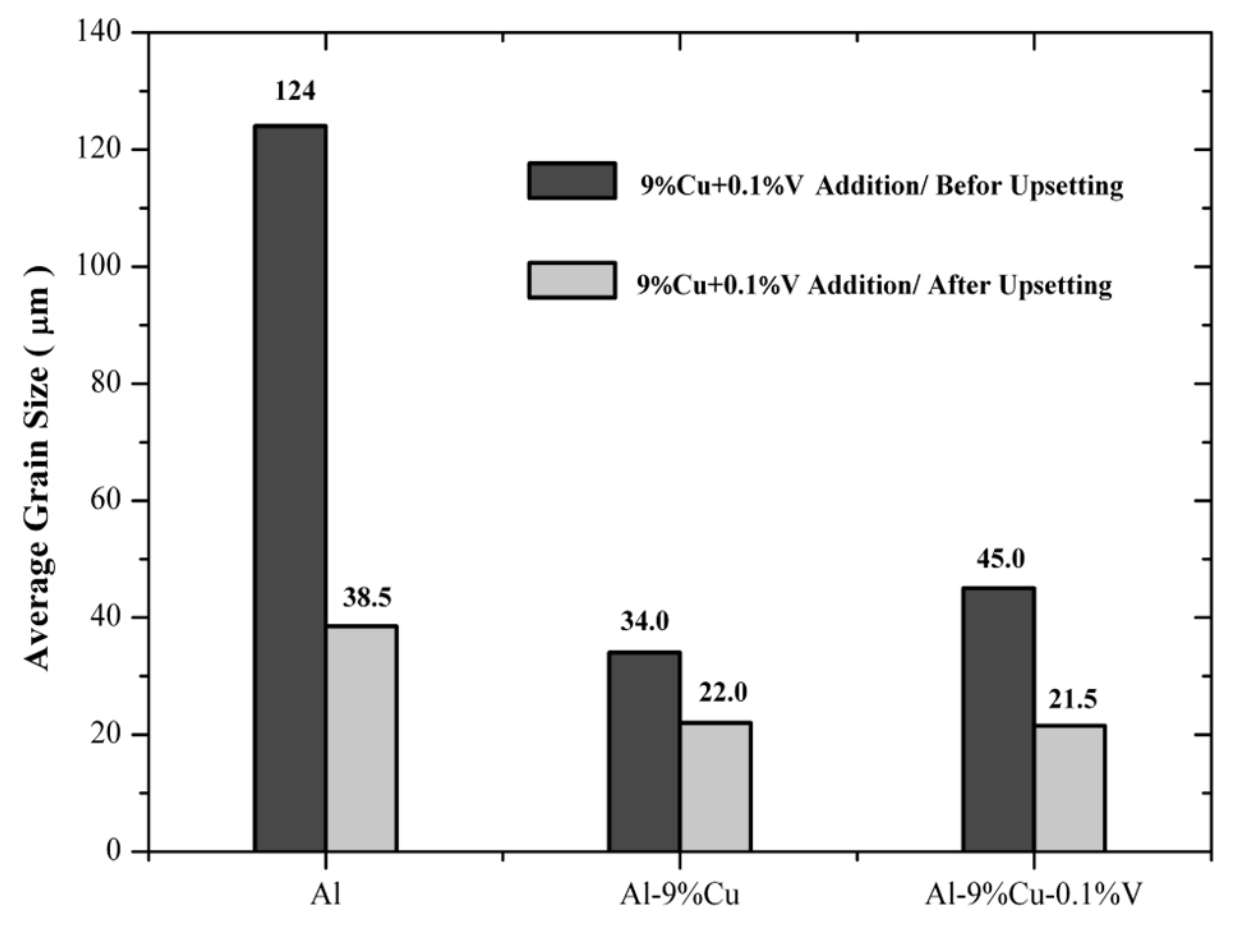

Al-Alloys

Figure 7. Average grain size of pure $\mathrm{Al}, \mathrm{Al}-9 \% \mathrm{Cu}$ alloy, and $\mathrm{Al}-9 \% \mathrm{Cu}-0.1 \% \mathrm{~V}$ alloy before and after upsetting process

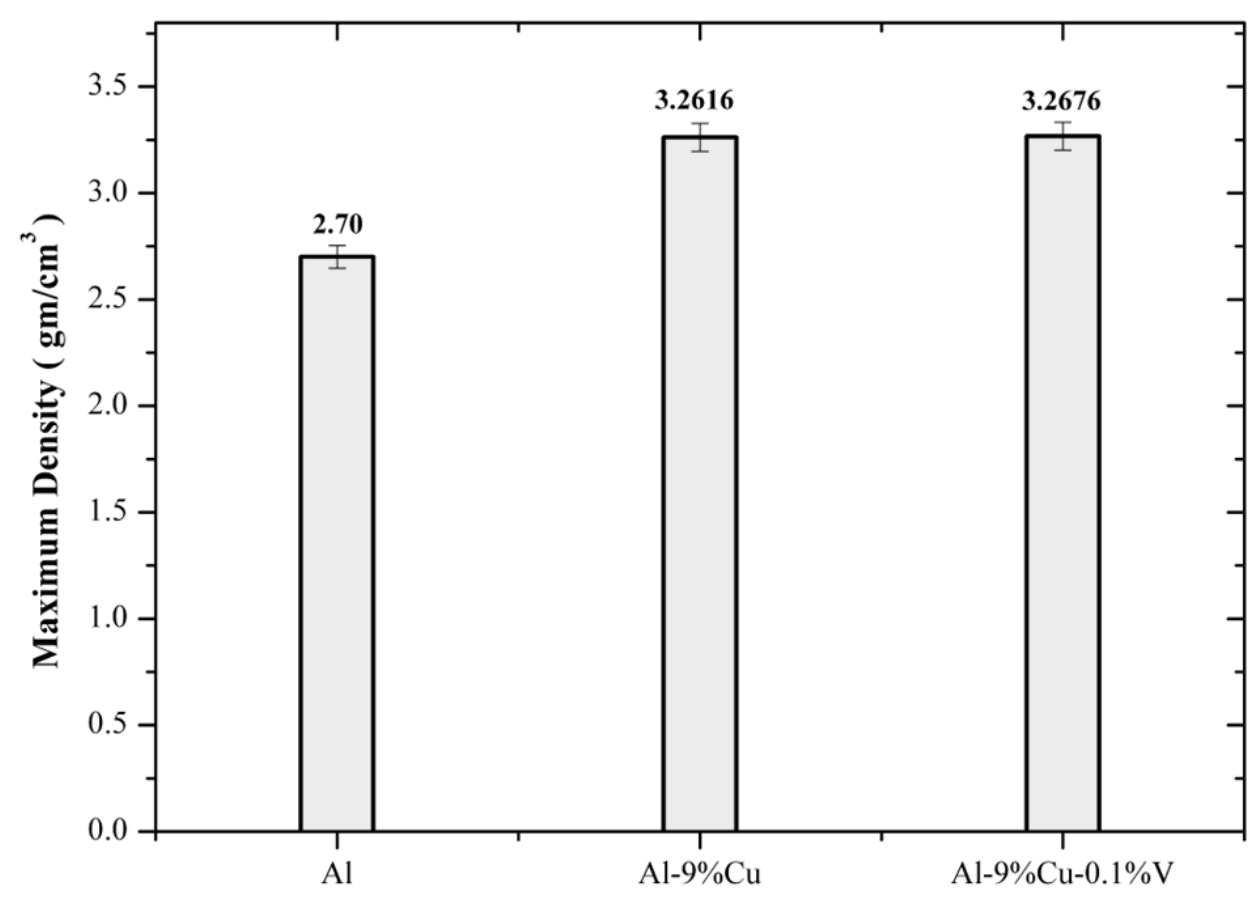

Al-Alloys

Figure 8. Maximum density of the $\mathrm{Al}$ casted alloys 


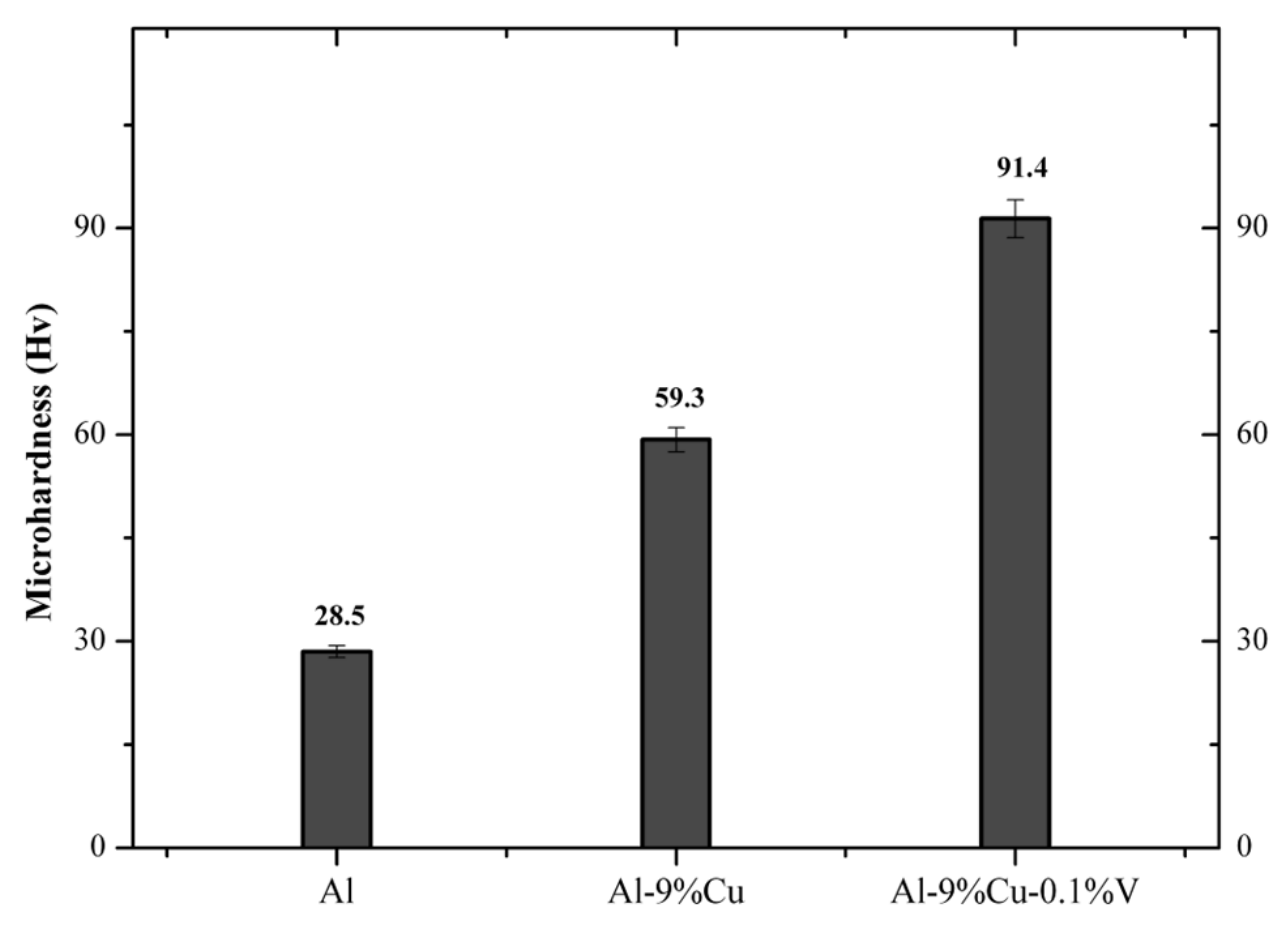

Al-Alloys

Figure 9. Effect of $9 \% \mathrm{Cu}$ and $0.1 \% \mathrm{~V}$ addition on the microhardness of pure $\mathrm{Al}$ before upsetting process

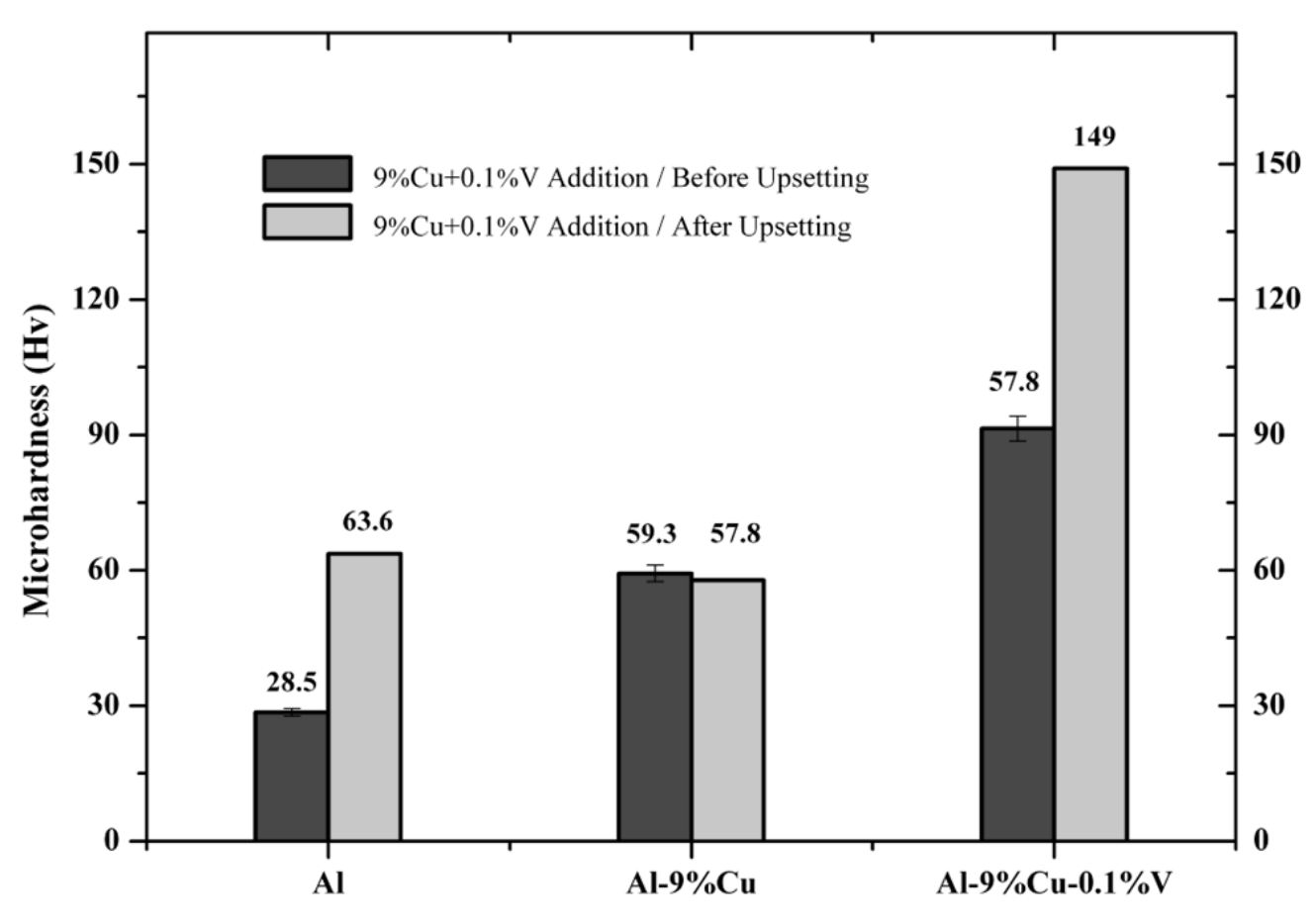

Al-Alloys

Figure 10. Effect of $9 \% \mathrm{Cu}$ and $0.1 \% \mathrm{~V}$ addition on the microhardness on pure $\mathrm{Al}$ before and after upsetting process 


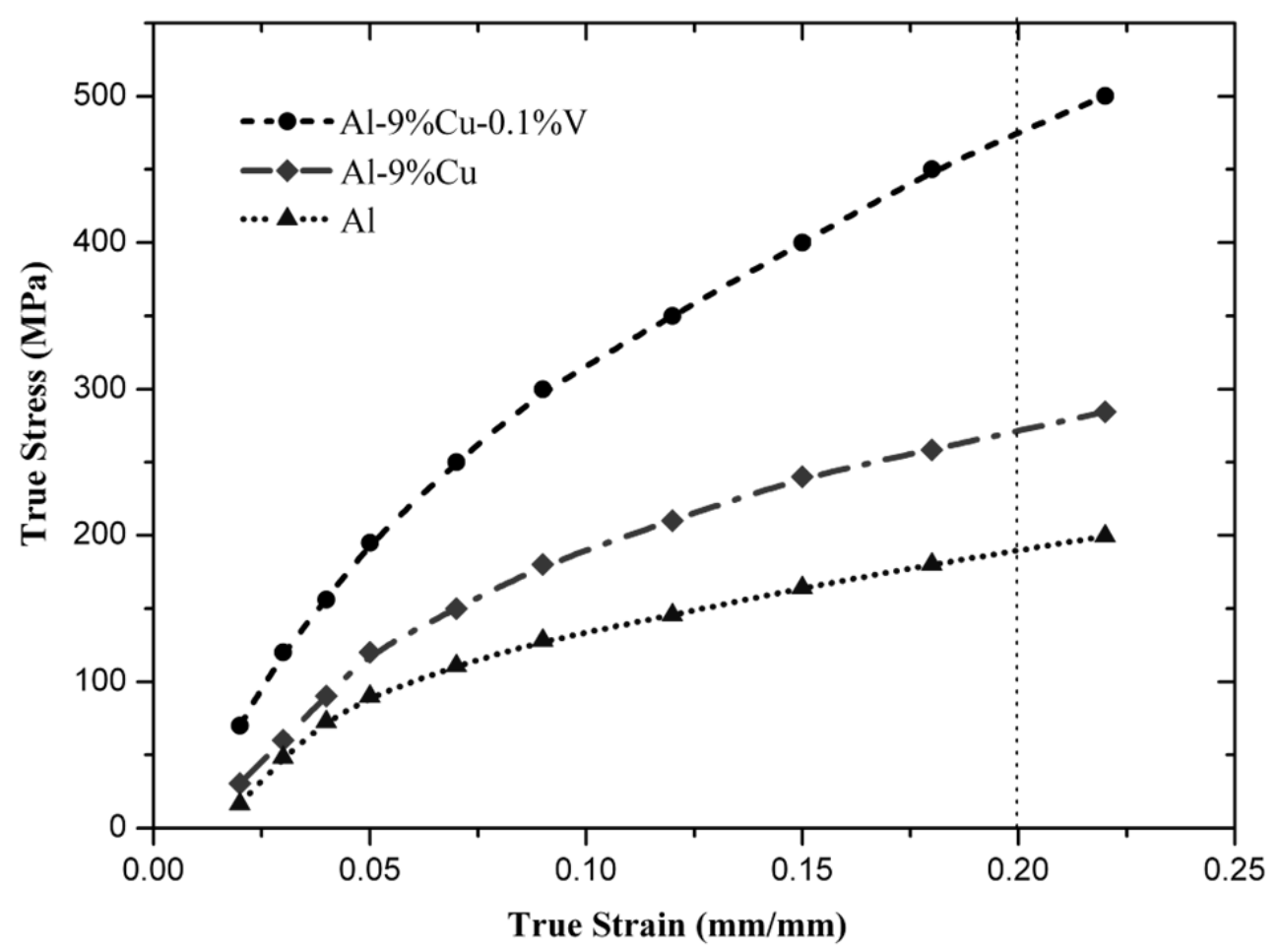

Figure 11. Effect of $9 \% \mathrm{Cu}$ and $0.1 \% \mathrm{~V}$ addition on the mechanical characteristics of pure $\mathrm{Al}$ 